\title{
Gross Anatomical Studies on the Adrenal Gland in Prenatal Goat (Capra hircus)
}

\author{
Estudio Anatómico Macroscópico de la Glándula Suprarrenal en Fetos de Cabra (Capra hircus)
}

Satish K. Pathak*; M. M. Farooqui"; Prabhakar Kumar*; Ajay Prakash*; Archana Pathak* \& Dharmendra Singh*

PATHAK, S. K.; FAROOQUI, M. M.; KUMAR, P.; PRAKASH, A.; PATHAK, A. \& SINGH, D. Gross anatomical studies on the adrenal gland in prenatal goat (Capra hircus). Int. J. Morphol., 32(1):131-135, 2014.

SUMMARY: The present study was conducted on the 24 healthy and normal embryos/foeti of non- descript goat (Capra hircus) varying from day old to 150 days of gestation. The embryo/foeti were assigned into three groups according to their gestational ages; Groups I (0-50 days), II (51-100 days) and III (101-till term). At 38 days of gestation the primordia of right and left adrenal gland were observed as a pea shaped spherical swelling located just cranial to the respective metanephros. Biometrical studies revealed the increase in the all parameters of the adrenal gland with the advancement of age. Adrenal glands were harvested first grossly at 50 days of gestation.

KEY WORDS: Goat; Adrenal gland; Gross anatomy; Fetus.

\section{INTRODUCTION}

The adrenal gland plays an important role in maintenance of electrolyte concentration in extracellular fluid, regulate carbohydrate metabolism and has a musculinizing effect as testosterone (Aughey \& Frye, 2001). Hyperactivity of the foetal adrenal cortex has been reported in crossbred goats towards the end of pregnancy (Ashok et al., 2000). Publication devoted to morphometrical studies on the adrenal gland in goat is scanty; therefore present research was conducted to record the growth spurt and morphological features during different stage of gestation.

\section{MATERIAL AND METHOD}

The present study was conducted on 24 embryos/foeti of goat (Capra hircus) from 0-150 days of gestation. Immediately after collection, the umbilical cord of these embryos/foeti were ligated properly and was cleaned with cotton soaked with water to remove the amniotic fluid. Each embryos/foeti was measured for its crown rump length (CRL) in centimeter with the help of nylon tape and weighed in gram with the aid of electronic weighing balance machine. The approximate age of foeti was estimated by using the formula derived by Singh et al. (1979) in goat. The embryo/ foeti were assigned into three groups according to their gestational ages; Groups I (0-50 days), II (51-100 days) and III (101-till term).

\section{RESULTS AND DISCUSSION}

In group-I (0-50 days of gestation), in prenatal goat, at 38 days of gestation the primordia of right and left adrenal gland were observed as a pea shape spherical swelling located just cranial to the respective metanephros and these were relatively larger and somewhat rounded at 44 days of gestation. At 50 days of gestation, rounded adrenals were placed under the last ribs. Both the glands were same in weight, length, thickness and width. These were located a little cranial to the cranial extremity of the respective kidneys. The adrenal glands were first harvested grossly at this stage of development (Fig. 1A and B). Ashok et al. reported that 
adrenals acquired a harvestable size around 59 days of gestation. Sisson (1911) mentioned that adrenal glands lied in contact with the cranial part of the inner border of kidneys in adult domestic animals.

In group-II (51-100 days of gestation), at 53 days of gestation, left adrenal gland was located near to second lumbar vertebra whereas right was near to first lumbar vertebra. Both glands were attached to the cranial extremity of respective kidney, but were separated from the kidney by a little fibro-alveolar tissue. The right adrenal appeared to be isosceles triangle whose angles were rounded off, while the left was roughly bean shape. The left gland presented: two surfaces viz. cranial and caudal and two borders medial and lateral whereas right had two surfaces cranial and caudal and three borders cranial, medial and lateral. The lateral border of the left adrenal gland was convex whereas medial border of the left showed a slight depression indicated the beginning of concavity. All the borders of right adrenal gland were slightly convex. The cranial surface of left adrenal gland from above downwards was related to the dorsal sac of rumen, the renal artery and the left lobe of pancreas and the upper end was related to the caudal extremity of the developing spleen. The caudal surface of left adrenal gland was related to the kidney laterally and the left crus of the diaphragm medially. The cranial surface of right adrenal was devoid of peritoneum except for a small part caudally and medially it was related to caudal vena cava, laterally related to right lobe of liver and caudally it was related to duodenum. The caudal surface of right adrenal gland was related to right crus of the diaphragm. The left adrenal gland had two ends the upper one was narrow and lower was rounded, whereas right had apex and base. The apex of right adrenal was related to upper pole of right kidney. At 55 days of gestation, the right adrenal was pyramidal in shape, while left was bean shaped. The lateral border of right adrenal was convex in anterior one third (1/3rd) parts and straight at the caudal two third (2/3rd) part, the medial border was deeply concave, whereas cranial border was convex. The lateral border of left was somewhat straight whereas medial border was slightly concave at upper part and concave at lower part. The caudal extremity of right was narrow, while cranial extremity was broad.

At 60 days of gestation (Figs. 2 and 3) and onward adrenals showed similar morphological features as observed at 55 days of gestation except there was increase in biometrical parameters. Morphological features viz surfaces; border and extremities observed in the present study were in agreement with the description of Sisson in adult domestic animals. The overall averages length, width and thickness of left adrenal gland in group -II were 4.94 $\pm 0.39,2.63 \pm 0.18$, and $1.91 \pm 0.11 \mathrm{~mm}$, respectively. The same parameters of right adrenal gland were $4.50 \pm 0.50,2.69 \pm 0.21$, and $1.89 \pm 0.12 \mathrm{~mm}$, respectively. The mean weights of the left and right adrenal glands were $17.00 \pm 4.08$ and $15.75 \pm 3.93$ $\mathrm{mg}$, respectively. The statistical analysis of various biometrical parameters revealed highly significant difference between left and right adrenal gland for length, width, thickness and weight. The left adrenal gland always showed higher values than the right adrenal gland for length, thickness and weight while it was reverse in case of width. The various parameters of adrenal gland were highly significantly correlated with age of foetus $(\mathrm{P}<0.01)$. The ' $\mathrm{R}$ ' value of age with length, width, thickness and weight of left adrenal gland were $0.957,0.843,0.941$ and 0.988 , respectively. The same parameters of right adrenal gland were $0.973,0.910,0.930$ and 0.986 respectively. The length, thickness and weight of left adrenal gland and length, width, and weight of right adrenal gland were highly significantly correlated with weight of the foetus $(\mathrm{P}<0.01)$, while width of left adrenal gland and thickness of right adrenal gland were significantly correlated with weight of the foetus $(\mathrm{P}<0.05)$. Growth spurt showed the left adrenal was longer, thicker and heavier than the right from 50 days of gestation onwards. It showed that the length, width, thickness and weight of both glands increased simultaneously with age.

In group-III (101 days-full term of gestation), topographic and morphological features of left and right adrenal were resembled with group-II. There was abrupt increase in weight of adrenal gland, which was parallel to the increase the body weight towards the term (Fig. 4), similar trend of growth spurt in goat foetuses observed by Ashok et al. Jost (1975) recorded a steady increase in the foetal adrenal weight during pregnancy, especially towards the end of gestation has been reported in man. The sharp increase in adrenal weight from 141 days to term was also noticed in sheep foeti (Thurley, 1972). The adrenal weight doubled from 136 to birth in sheep fetuses (Boshier et al., 1989). Similar trend was reported in equine (Yamuchi, 1979) and in swine (Lohse \& First, 1981). The left adrenal gland was always slightly heavier than right adrenal gland. The left adrenal gland was always larger in size than right adrenal gland. The overall averages length, width and thickness of the left adrenal gland in group -III were 7.63 \pm 0.42 , $4.31 \pm 0.28$ and $2.95 \pm 0.18 \mathrm{~mm}$, respectively. The same parameters of right adrenal gland were $6.75 \pm 0.37,4.59 \pm 0.14$ and $2.93 \pm 0.17 \mathrm{~mm}$, respectively. The mean weights of the left and right adrenal gland were 69.75 \pm 16.29 and $67.88 \pm 16.05 \mathrm{mg}$, respectively. In group- III, all biometrical parameters of adrenal gland increased significantly from group II. The length of left adrenal gland increased from $4.94 \mathrm{~mm}$ to $7.63 \mathrm{~mm}$, width increased from $2.63 \mathrm{~mm}$ to 4.31 $\mathrm{mm}$, thickness increased from 1.91 to $2.95 \mathrm{~mm}$ and weight increased from $17.00 \mathrm{mg}$ to $69.75 \mathrm{mg}$ that is more than 4 


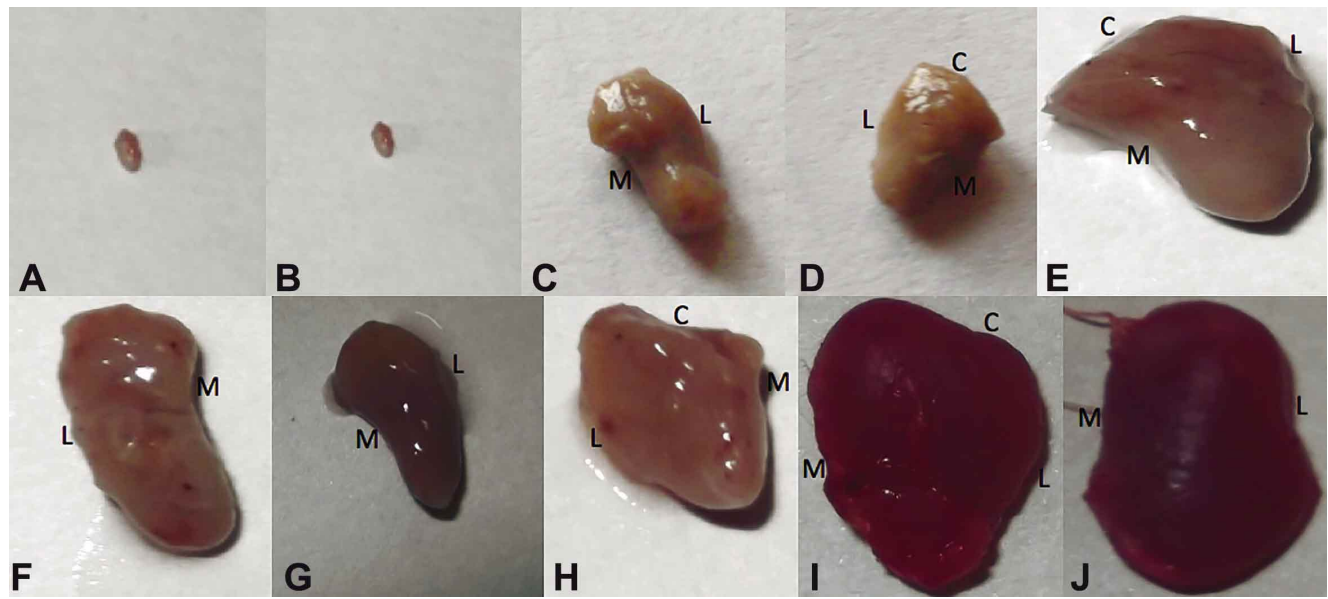

Fig. 1. A. Photograph of left adrenal gland of 50 days old goat foetus; B. Right adrenal gland of 50 days old goat foetus; C. Left adrenal gland (cranial view) of 100 days old goat foetus showing borders medial (M) and lateral (L); D. Right adrenal gland (caudal view) of 100 days old goat foetus showing borders cranial (C), medial (M) and lateral (L); E. Right adrenal gland (cranial view) of 101 days old goat foetus showing borders cranial (C), medial (M) and lateral (L); F. Left adrenal gland (caudal view) of 101 days old goat foetus showing borders medial (M) and lateral (L); G. Left adrenal gland (cranial view) of 118 days old goat foetus showing borders medial (M) and lateral (L); H. Right adrenal gland (caudal view) of 118 days old goat foetus showing borders cranial (C), medial (M) and lateral (L); I. Left adrenal gland (cranial view) of full term goat foetus showing borders medial (M) and lateral (L); J. Right adrenal gland (cranial view) of full term goat foetus showing borders cranial (C), medial (M) and lateral (L).

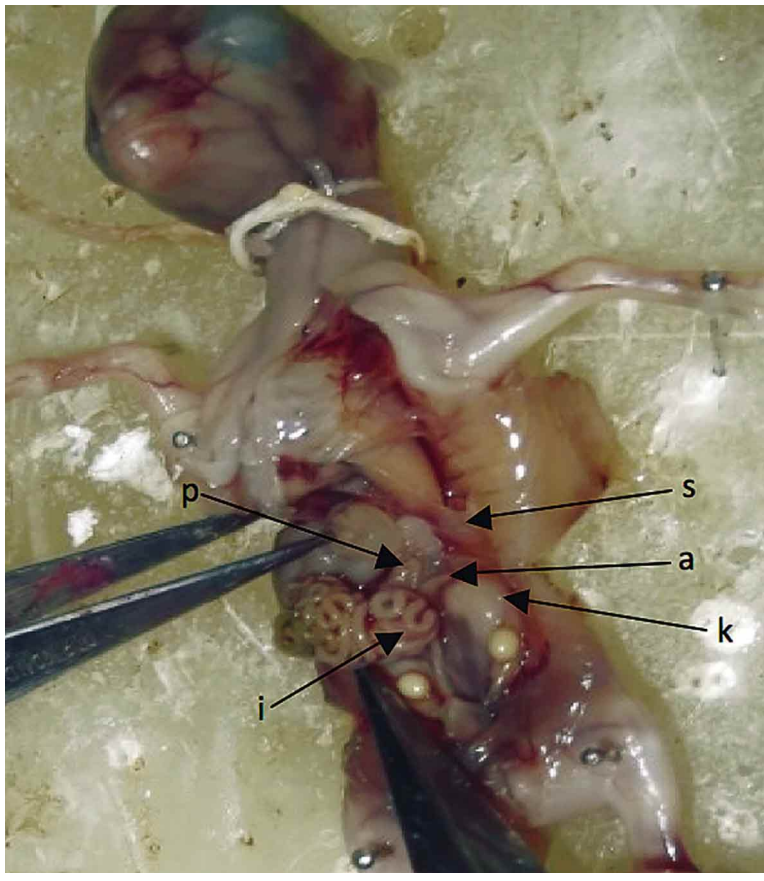

Fig. 2. Photograph of 60 days old goat foetus showing left Adrenal gland (a) kidney (k), spleen (s), intestine (i) and pancreas (p).

times from the group- II in group- III. The length of right adrenal gland increased from $4.50 \mathrm{~mm}$ to $6.75 \mathrm{~mm}$, width increased from $2.69 \mathrm{~mm}$ to $4.59 \mathrm{~mm}$, thickness increased from $1.89 \mathrm{~mm}$ to $2.93 \mathrm{~mm}$ and weight increased from 15.75

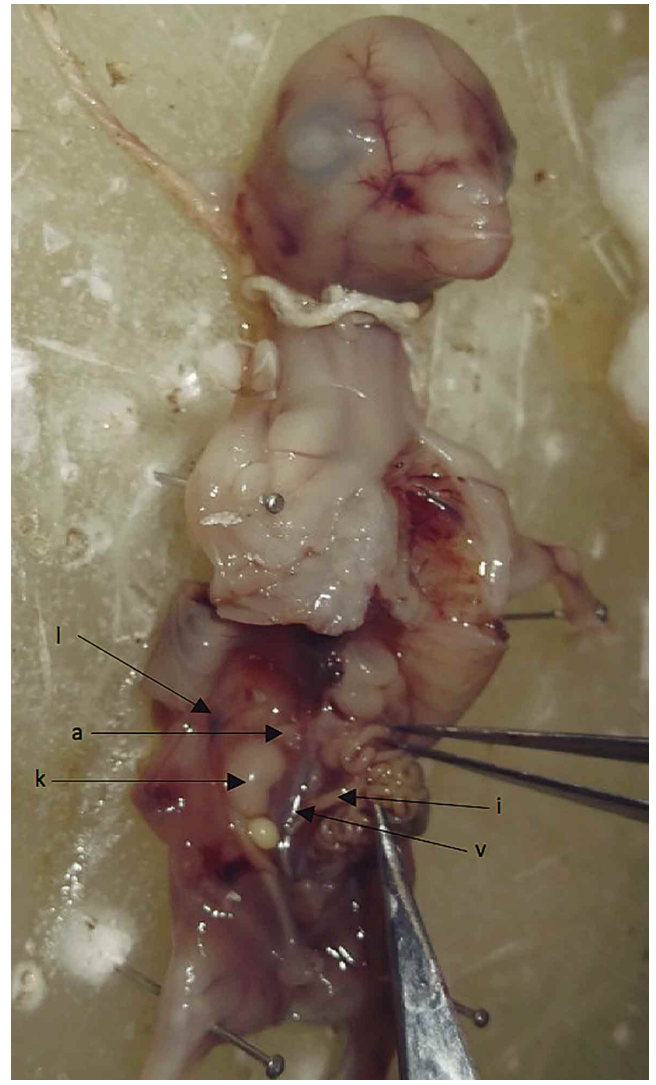

Fig. 3. Photograph of 60 days old goat foetus showing right adrenal gland (a) ,kidney (k), intestine (i), vena cava (v) and part of liver (l). 


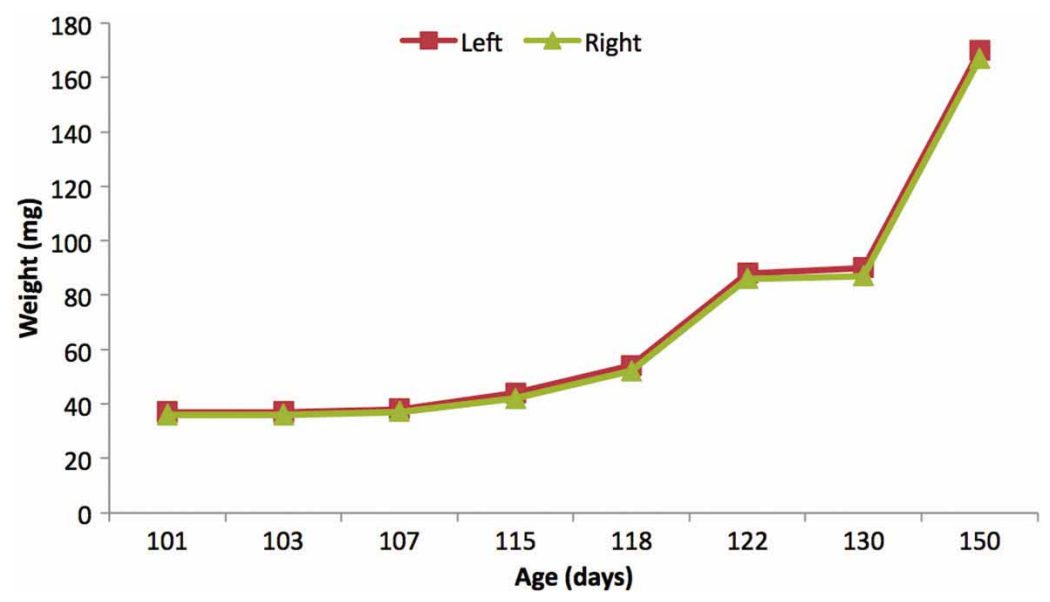

Fig. 4. Graph showing the changes in weight of both adrenal glands with age in prenatal goat in group-III.

$\mathrm{mg}$ to $67.88 \mathrm{mg}$ that is more than 4 times from the group-II in group-III. The biometrical parameters were highly significantly correlated with age of foetus $(\mathrm{P}<0.01)$. The ' $\mathrm{R}$ ' value of age with length, width, thickness and weight of left adrenal gland were $0.951,0.928,0.949$ and 0.959 respectively. The same parameters of right adrenal gland were $0.944,0.856,0.946$ and 0.956 respectively. The length, width and weight of left adrenal gland and length and weight of right adrenal gland were highly significantly correlated with weight of the foetus $(\mathrm{P}<0.01)$, while thickness of left adrenal gland and width and thickness of right adrenal gland significantly correlated with weight of the foetus $(\mathrm{P}<0.05)$. The average weights of both the adrenals in group-III were significantly higher than the average weights of both adrenals in group-II. Similar trend was reported in the foetal adrenal gland of crossbred goat (Ashok et al.). They further observed adrenal weight was positively correlated with age and body weight of foetuses. Weight of right and left adrenals were significantly higher after 106 days of gestation. In the present study the weight was significantly higher in group-III.

\section{CONCLUSION}

At 38 days of gestation the primordia of right and left adrenal gland was observed as a pea shaped spherical swelling located just cranial to the respective metanephros. Adrenal glands were harvested first grossly at 50 days of gestation. Biometrical studies revealed the increase in all parameters of the adrenal gland with the advancement of age. The left adrenal gland was heavier, thicker and longer than the right adrenal gland in all the groups. The biometrical parameters were highly significantly correlated with the age of foetus $(\mathrm{P}<0.01)$. From the above study it is concluded that weight and other parameters of the adrenals increased constantly up to full term. The length, weight and thickness were positively correlated with the age of foetus (Table I).

Table I. Morphological Parameters (Mean \pm SE) of Adrenal gland in prenatal goat in various gestation periods $(n=8)$.

\begin{tabular}{|c|c|c|c|c|c|}
\hline \multirow{2}{*}{ S. $\mathbf{n}$} & \multirow{2}{*}{ Parameters } & \multicolumn{2}{|c|}{ Group -II } & \multicolumn{2}{|c|}{ Group -III } \\
\hline & & Left & Right & Left & Right \\
\hline \multirow{2}{*}{1} & Length ( $\mathrm{mm}$ ) & $4.94^{\mathrm{a} \pm}-0.39$ & $4.50^{\mathrm{b} \pm}{ }^{-} 0.50$ & $7.63^{\mathrm{a} \pm}-0.42$ & $6.75^{\mathrm{b} \pm}-0.37$ \\
\hline & Range & $(3.5-6)$ & (3-6) & $(6-10)$ & (6-9) \\
\hline \multirow{2}{*}{2} & Width (mm) & $2.63^{\mathrm{c} \pm}-0.18$ & $2.69^{\mathrm{d} \pm}-0.21$ & $4.31 \pm 0.28$ & $4.59 \pm 0.14$ \\
\hline & Range & $(2-3)$ & $(2-3.5)$ & $(3.5-6)$ & $(4-5)$ \\
\hline \multirow{2}{*}{3} & Thickness (mm) & $1.91^{\mathrm{e} \pm} 0.11$ & $1.89 \mathrm{f} \pm 0.12$ & $2.95^{\mathrm{c} \pm} 0.18$ & $2.93^{\mathrm{d} \pm}-0.17$ \\
\hline & Range & $(1.4-2.2)$ & $(1.3-2.2)$ & $(2.5-3.6)$ & $(2.5-3.5)$ \\
\hline \multirow{2}{*}{4} & Weight (mg) & $17.00 \mathrm{~g} \pm 4.08$ & $15.75^{\mathrm{h} \pm} .93$ & $69.75^{\mathrm{e} \pm} 16.29$ & $67.88^{\mathrm{d} \pm} 16.05$ \\
\hline & Range & $(4-34)$ & $(3-33)$ & (37-170) & $(36-167)$ \\
\hline
\end{tabular}

$\mathrm{a}, \mathrm{b}, \mathrm{c}, \mathrm{d}, \mathrm{e}, \mathrm{f}, \mathrm{g}$ and $\mathrm{h}$ superscript showed the significant difference within groups. 
PATHAK, S. K.; FAROOQUI, M. M.; KUMAR, P.; PRAKASH, A.; PATHAK, A. \& SINGH, D. Estudio anatómico macroscópico de la glándula suprarrenal en fetos de cabra (Capra hircus). Int. J. Morphol., 32(1):131-135, 2014.

RESUMEN: El presente estudio se realizó en 24 embriones / fetos de cabra (Capra hircus) sanos de un día hasta los 150 días de gestación. Los embriónes fueron separados en tres grupos de acuerdo a la edad gestacional: grupos I (0-50 días), II (51 a 100 días) y III (101-till plazo). A los 38 días de gestación se observó el primordio de las glándulas suprarrenales derecha e izquierda como una protuberancia de forma esférica, situada justo en la zona craneal en relación al metanefros. C on el avance de la edad, estudios biométricos revelan aumento de todos los parámetros de la glándula suprarrenal. Las glándulas suprarrenales fueron extraídas inicialmente a los 50 días de gestación.

PALABRAS CLAVE: Cabra; Glándula suprarrenal; Anatomía macroscópica; Feto.

\section{REFERENCES}

Ashok, N.; Harshan, K. R. \& Chungath, J. J. Histological development and organization of the adrenal cortex in the crossbred goat. Proceedings of the 12th Kerala Science Congress, January, Kumily, 2000. pp.329-32.

Aughey, E. \& Frye F. L. Comparative veterinary histology with clinical correlates. London, Manson Pub. Ltd., 2001.

Boshier, D. P.; Gavin, C. B. \& Holloway, H. Morphometric analyses of adrenal gland growth in fetal and neonatal sheep. II The adrenal medulla, with some observations on its ultrastructure. J. Anat., 167:15-30, 1989.

Jost, A. The fetal adrenal cortex. In: Handbook of Physiology. Vol. VI. Adrenal gland. Greep, R. O. \& Eastwood, E. B. (Eds.). Washington DC, American Physiological Society, 1975. pp.107-15.

Lohse, J. K. \& First, N. L. Development of the porcine fetal adrenal in late gestation. Biol. Reprod., 25(1):181-90, 1981.

Singh, Y.; Sharma, D. N. \& Dhingra, L. D. Morphogenesis of the testis in goat. Indian J. Anim. Sci., 49(11):925-31, 1979.

Sisson, S. B. A Text-Book of Veterinary Anatomy. Philadelphia And London, W. B. Saunders Company 1911.

Thurley, D. C. Prenatal growth of Lhe adrenal gland in sheep. $N$. Z. Vet. J., 20(10):177-9, 1972.

Yamauchi, S. Histology development of the equine fetal adrenal gland. J. Reprod. Fertil. Suppl., (27):487-91, 1979.

\section{Correspondence to:}

Dr. M.M. Farooqui (Associate Professor)

Department of Veterinary Anatomy

College of Veterinary Science \& Animal Husbandry

Mathura (Uttar Pradesh) 281001

INDIA

Mobile no. +919927773888

Email: mmfarooqui64@gmail.com satishpathak26@hotmail.com

Received: 21-09-2013

Accepted: 23-12-2013 